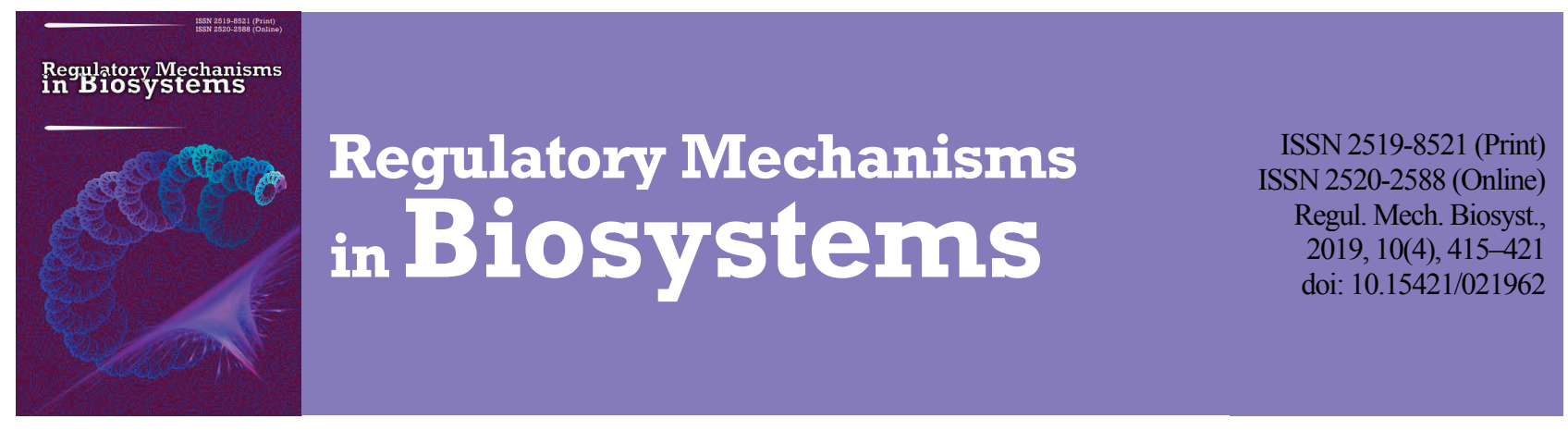

\title{
Peculiarities of microstructure of the suprarenal glands of rabbits with different types of autonomic tone
}

\author{
M. V. Zakrevska, A. M. Tybinka \\ Stepan Gzhytskyi National University of Veterinary Medicine and Biotechnologies, Lviv, Ukraine
}

Article info

Received 11.10.2019

Received in revised form 06.11 .2019

Accepted 07.11.2019

Stepan Gzhytskyi

National University

of Veterinary Medicine

and Biotechnologies,

Pekarska st., 50,

Lviv, 79010, Ukraine

Tel.: +38-067-454-75-10.

E-mail:

martazakrevska@gmail.com

\section{Zakrevska, M. V., \& Tybinka, A. M. (2019). Peculiarities of microstructure of the suprarenal glands of rabbits with different types of autonomic tone. Regulatory Mechanisms in Biosystems, 10(4), 415-421. doi:10.15421/021962}

The article investigates the structure of the suprarenal (adrenal) glands of male rabbits (Oryctolagus cuniculus), in which, on the basis of electrocardiographic and variational-pulsometric studies, different types of autonomic tone were observed. This allowed the animals to be divided into three groups: 1) sympathicotonic rabbits; 2) normotonic rabbits; 3) parasympathicotonic rabbits. The animals of the first two groups were characterized by almost the same body weight, while weight of the rabbits of the third group was slightly higher. After euthanasia, the suprarenal glands were extracted for histological and histochemical analyses. Morphometric study of histopreparations revealed that in the normotonic rabbits the thickness of the zona glomerulosa and zona fasciculata of the suprarenal glands were of average sizes, and the area of the medulla was the smallest. The parasympathicotonic rabbits had the thickest zona glomerulosa and greatest area of the medulla, but the thinnest zona fasciculata. The sympathicotonic rabbits were observed to have the greatest thickness of the zona fasciculata of the suprarenal glands, the area of the medulla was of average values, and the thickness of the zona glumerulosa was of minimum value. The type of autonomic tone also manifests in the saturation of each of the zones with cells. The normotonic rabbits were observed to have the highest number of cells per area of $1,000 \mu \mathrm{m}^{2}$ in the zona fasciculata and the medulla, sympathicotonic rabbits - in the zona glomerulosa and zona reticularis, and in parasympathicotonic rabbits this parameter had average or lowest values in all the zones. The sizes of cells and their structural parts were characterized on the basis of nuclear-cytoplasmic ratio. In the zona fasciculata and medulla this parameter was highest among parasympathicotonic rabbits, and lowest in sympathicotonic rabbits. In the zona glomerulosa, almost equal values were observed in the normotonic and parasympathicotonic rabbits, while being reliably lower in sympathicotonic rabbits. By the value of nuclear-cytoplasmic ratio in the zona reticularis, the normotonic rabbits dominated, followed by the sympathicotonic animals, and the parasympathicotonic rabbits had the lowest parameters.

Keywords: adrenal glands; sympathicotonic rabbits; normotonic rabbits; parasympathicotonic rabbits.

\section{Introduction}

The suprarenal (adrenal) glands near the thyroid and parathyroid glands are peripheral endocrine organs (Zhedenov, 1987). During embryogenesis, the adrenal glands form from the epithelium tissue (cortex of the suprarenal glands) and neuroendocrine chromaffin cells of the nervous (medulla) (Huber et al., 2002; Huber et al., 2009). Chromaffin cells together with sympathicotonic neurons develop from the same predecessors - sympathoadrenal cells (Huber, 2006; Unsicker et al., 2013). Therefore, already in that period, a close relationship between the suprarenal glands and nervous system is established, especially its sympathicotonic section.

The histological structure of the adrenal gland has been studied many times in different classes of animals taking into account their biological peculiarities and habitat (living conditions). Some species of amphibians have cells located chaotically and therefore the gland is not divided into zones, and chromaffin cells have granules of adrenaline and noradrenaline (Milano \& Accordi, 1986; Capaldo et al., 2006; Crivellato et al., 2009). Seasonal changes in activity of the gland, and also its intrauterine development, as links of philogenesis, were studied in reptiles (Lofts et al., 1971; Rupik, 2002; Chimenti \& Accordi, 2013). In the changes, the histochemical peculiarities of chromaffin cells were found (Orezzoli et al., 1994). Birds have two types of chromaffin cells (epinephrocytes and norepinephocytes) (Sonjoy et al., 2014; Moawad \& Randa, 2017). These cells are also characterized by chaotic arrangement, though in the gland, subcapsular layer, central and peripheral zones are distinguished (Humayun et al., 2012; Ye et al., 2018). The glands of ruminants were studied in the age and sex aspects (Jelinek \& Konecny, 2011; Fiadotau, 2015), and also with respect to breed (Paul et al., 2016) or species peculiarities (Barszcz et al., 2016). The mentioned factors also influence the structure of the suprarenal glands of numerous species of rodents (Sheikhian et al., 2014; Olukole et al., 2016; Santos et al., 2016; Finco \& Hammer, 2018). Significant species peculiarities were determined in the structure of the suprarenal glands of cetaceans (Vuković et al., 2010) and primates (Tachibana et al., 2015; Raharison et al., 2017). Among the studied animals, surveys frequently detected rabbits in which the structure of the suprarenal glands was studied from the perspective of embryogenesis (Sokolov, 1969; Hussein et al., 2015), blood circulation (Kigata \& Shibata, 2018), physiological and pathological conditions (Vinson et al., 1985; Baine et al., 2014) and impact of chemical substances (Chandra, 1975; McCreedy \& Harmon, 1992). Special attention in morphological studies is paid to the cellular content of the suprarenal glands. Their cells were found to have different structure and function, depending on the zone to which they belong (Pihlajoki et al., 2015; Vinson, 2016). Each zone produces hormones responsible for a broad spectrum of functional processes in the animal organism, including secondary sex features, blood pressure, mineral and carbohydrate metabolisms, and also stress (Dumbell et al., 2016; GalloPayet et al., 2017; Nicolaides et al., 2017; Sunwoo et al., 2019). Innervation of the suprarenal glands from the sympathicotonic section of the autonomic nervous system is performed through the nerves of the vertebral column, and also abdominal, mesenteric and renal plexuses. Para- 
sympathicotonic innervation is provided by the vagus nerve (Ramey \& Goldstein, 1957; Parker et al., 1993).

The different tones of the sympathicotonic and parasympathicotonic centers condition formation of separate types of autonomic regulation in the animal organism, which affect its morphology. Similar effects on the structure of additional suprarenal glands have been observed in rabbits (Zakrevska \& Tybinka, 2019). However, none of the previous studies have found a relationship between the morphology of the "main" suprarenal glands and typological peculiarities of the tone of the autonomic centers. Therefore this became the objective of our study.

\section{Materials and methods}

For the study, according to the principle of analogues, 27 four month old male rabbis (Oryctolagus cuniculus) of breed Blanc de Termonde were selected. The animals underwent electrocardiographic and variationpulsometric analyses, which allowed determination of their individual types of the autonomic tone (Baevskij et al., 1984). The speed of ECG during recording of the cardiosignal was $250 \mathrm{~mm} / \mathrm{s}$. According to the results of these studies, the rabbits were divided into three groups: sympathicotonic (ST) - 19 rabbits, normotonic (NT) - 5 rabbits and parasympathicotonic (PS) - 3 rabbits. All the animals were weighed with accuracy of up to two grams. For selection of histological material, the rabbits were euthanized by inhalational overdosing with chloroform. From each animal the suprarenal glands were extracted (Fig. 1).

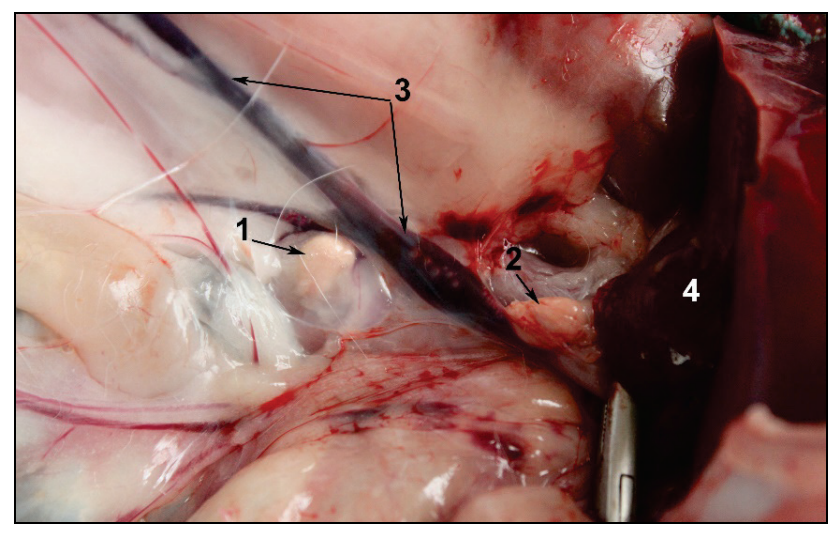

Fig. 1. Suprarenal glands of rabbit:

1- left gland, 2 - right gland, 3 - caudal vena cava, 4 - liver

The right one was fixated in Bouin's fluid, dehydrated after $24 \mathrm{~h}$ through the graded alcohols and embedded into paraffin wax blocks. From the obtained blocks, using MC-2 microtome, $7 \mu \mathrm{m}$ thick sections were made, installed on the microscope slide, and after they had been dried, they were stained with Mayer's hematoxylene and eosin, Steedman alcian blue, Heidenhain's Azan and treated by Mc Manus PAS reaction (Pirs, 1962).

Also we used phenylhydrazine reaction for determining corticosteroids and chromaffin reaction according to Hillarp \& Hokfelt for detection of hormones of the medulla (Kononskiy, 1976). To perform these histological reactions, the left suprarenal gland was cut in half along the lengthwise axis and the obtained halves were fixated in Becker's fluid

Table 1

Sizes of the capsule and separate zones of the suprarenal glands $(x \pm S E)$ and mixture of potassium dichromate with potassium chromate correspondingly. Then, pieces of the organs were washed and embedded in gelatin. On a freezing microtome MZ-2, $20 \mu \mathrm{m}$ thick sections were made, installed on the microslide and embedded in polyvinyl alcohol. The prepared preparations were examined under the microscope with lenses of series HCX PL FLUOTAR with the zooms of $5 \mathrm{x} / 0.15$, $10 \mathrm{x} / 0.3,20 \mathrm{x} / 0.5,40 \mathrm{x} / 0.75$ and $100 \mathrm{x} / 1.3$. Digital images of preparations were obtained using a camera with the resolution of 5 megapixels. To perform morphometric surveys we used Aperio Image Scope software (Leica Microsystems GmbH, Germany, 2012). The morphometric method revealed the following parameters: thickness of the capsule of the suprarenal gland, thickness and area of separate zones (glomerulosa, fasciculata, reticularis, medulla), area of the cells and their nuclei in these zones, and also the number of cells per unit area $\left(1,000 \mu \mathrm{m}^{2}\right)$. For all the zones we determined nuclear-cytoplasmic ratio of the cells. In the cortex zone we also determined the area of accumulation of corticosteroids, and in the medulla - of catecholamines (adrenaline, noradrenaline). This study was undertaken by determining optical density of these areas using WCIF ImageJ program (WCIF, Canada, 2000).

The results were statistically analyzed in ANOVA with the use of StatPlus program (AnalystSoft Inc., USA, 2008). At the same time, we determined: $\mathrm{x}$ - selective average and SE - standard error. The differences between the groups of animals were considered significant at $\mathrm{P}<$ 0.05 taking into account Bonferroni correction.

\section{Results}

The results of morphometric studies indicate presence of relationship between the structure of the suprarenal glands and typological peculiarities of the autonomic tone. The thickest connective tissue capsule of the suprarenal gland was determined in the representatives of the sympathicotonic group (Table 1). In the animals of two other groups its thickness was less by $41.2 \mu \mathrm{m}$ in NT rabbits and $33.8 \mu \mathrm{m}$ in PS rabbits. These differences were caused by different amounts of fat inclusions and massive vessels in the capsule (Fig. 2, 3).

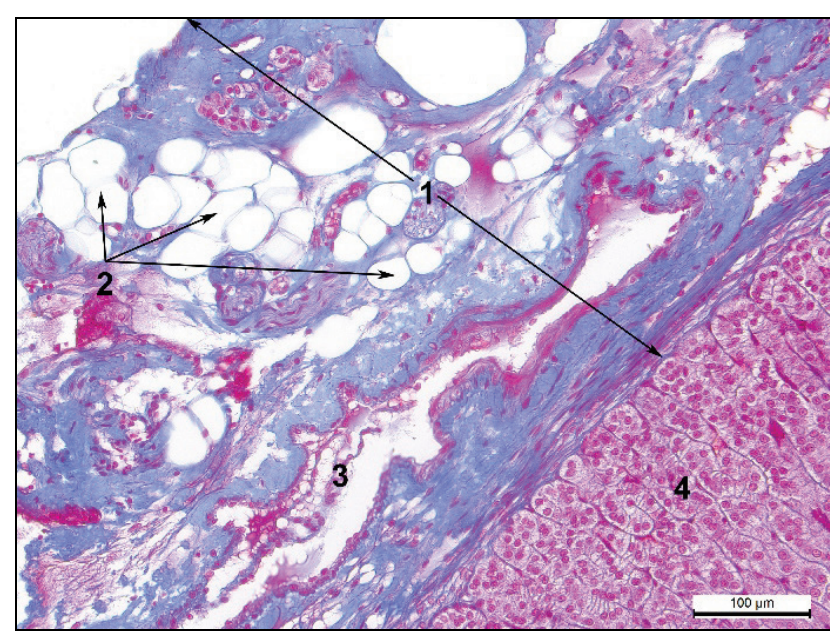

Fig. 2. Suprarenal gland of parasympathicotonic rabbit: 1 - capsule, 2 - fatty inclusions, 3 - vessel, 4 - zona glomerulosa. Heidenhain's Azan

\begin{tabular}{|c|c|c|c|}
\hline \multirow{2}{*}{ Parameter } & \multicolumn{3}{|c|}{ Group of rabbits } \\
\hline & sympathicotonic, $\mathrm{n}=19$ & normotonic, $\mathrm{n}=5$ & parasympathicotonic, $\mathrm{n}=3$ \\
\hline Thickness of the capsule, $\mu \mathrm{m}$ & $88.1 \pm 24.0$ & $46.8 \pm 16.6$ & $54.3 \pm 9.3$ \\
\hline Thickness of the zona glomerulosa, $\mu \mathrm{m}$ & $301 \pm 18$ & $333 \pm 90$ & $455 \pm 152$ \\
\hline Thickness of the zona fasciculata, $\mu \mathrm{m}$ & $1463 \pm 98$ & $1410 \pm 281$ & $1,308 \pm 205$ \\
\hline Area of the medulla, $\mathrm{mm}^{2}$ & $6.74 \pm 5.33$ & $0.34 \pm 0.10$ & $0.76 \pm 0.45$ \\
\hline Length of the medulla, $\mu \mathrm{m}$ & $2,707 \pm 378$ & $2,941 \pm 1,243$ & $2,897 \pm 1,521$ \\
\hline Width of the medulla, $\mu \mathrm{m}$ & $809 \pm 144$ & $307 \pm 56$ & $434 \pm 242$ \\
\hline Area of the cortex zone, occupied by corticosteroids, $\mu \mathrm{m}^{2}$ & $1,129 \pm 248$ & $1,485 \pm 501$ & $395 \pm 178$ \\
\hline Area of the medulla occupied by catecholamines, $\mu \mathrm{m}^{2}$ & $2,410 \pm 521$ & $2,850 \pm 499$ & $2,370 \pm 102$ \\
\hline
\end{tabular}




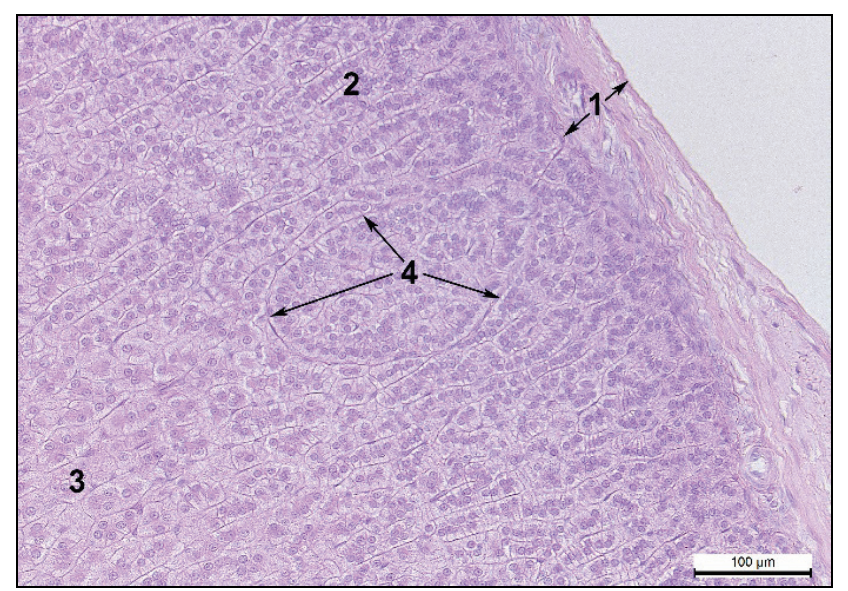

Fig. 3. Suprarenal gland of normotonic rabbit: 1 - capsule, 2-zona glomerulosa, 3 -zona fasciculata, 4 -additional suprarenal gland; hematoxylin and eosin

Studies of the internal structure of the suprarenal glands revealed significant differences between thickness of the zona glomerulosa and zona fasciculata, and also fluctuations in sizes and shapes of the medulla. Thickness of the zona glomerulosa in the parasympathiconic group (Fig. 4) was $154 \mu \mathrm{m}$ greater than that of the sympathicotonic groups. However, according to the data in Table 2, in parasympathicotonic rabbits, the number of cells per $1,000 \mu \mathrm{m}^{2}$ in this zone (Fig. 5) was 0.42 units lower than in the same area in sympathicotonic rabbits. Much smaller divergences were observed in the group of normotonic rabbits. Thickness of the zona glomerulosa in these animals was $32 \mu \mathrm{m}$ greater than in the sympathicotonic group, and the differences in the number of cells per unit area between these groups equaled 0.10 units.

The largest zone of the cortex of the suprarenal gland is the zona fasciculate. Its maximum thickness was observed in sympathicotonic animals and exceeded this value by $53 \mu \mathrm{m}$ in normotonic animals (Fig. 6) and by $155 \mu \mathrm{m}$ in parasympathicotonic animals. In the normotonics group (Fig. 7), the highest number of cells in this zone per unit area was observed and they exceeded the number for sympathicotonic rabbits by 0.71 units $(\mathrm{P}<0.01)$. Parasympathicotonic rabbits by number of cells in $1,000 \mu \mathrm{m}^{2}$ exceeded the sympathicotonic ones by 0.39 units. Therefore, in animals with normotonic type of autonomic nervous system, the zona fasciculata of the cortex was characterized by higher saturation with cells compared with the same zone in animals of other groups.

Special attention should be paid to the zona reticularis of the suprarenal gland, which interweaves with or surrounds the medulla (Fig. 8), and sometimes is completely absent. In this zone,the lowest quantity of cells per $1,000 \mu \mathrm{m}^{2}$ was observed in normotonic rabbits $-4.91 \pm 0.77$ units. This was 1.22 units less than in sympathicotonic animals (Fig. 9).
In parasympathicotonic animals the average parameter of the number of cells in this zone was 0.93 units lower than the parameter of the sympathicotonic group. Furthermore, parasympathicotonic rabbits had the smallest area of nuclei of these cells, with difference between them and sympathicotonic animals equaling $0.40 \mu \mathrm{m}^{2}$. During the study of optical density of corticosteroids in the cortex of the suprarenal glands (Table 1), we determined that their area was the largest in normotonic animals (Fig. 10) and exceeded that found in sympathicotonic ones by $356 \mu \mathrm{m}^{2}$. In parasympathicotonic rabbits this parameter was the lowest, being $734 \mu \mathrm{m}^{2}$ less than in sympathicotonic animals.

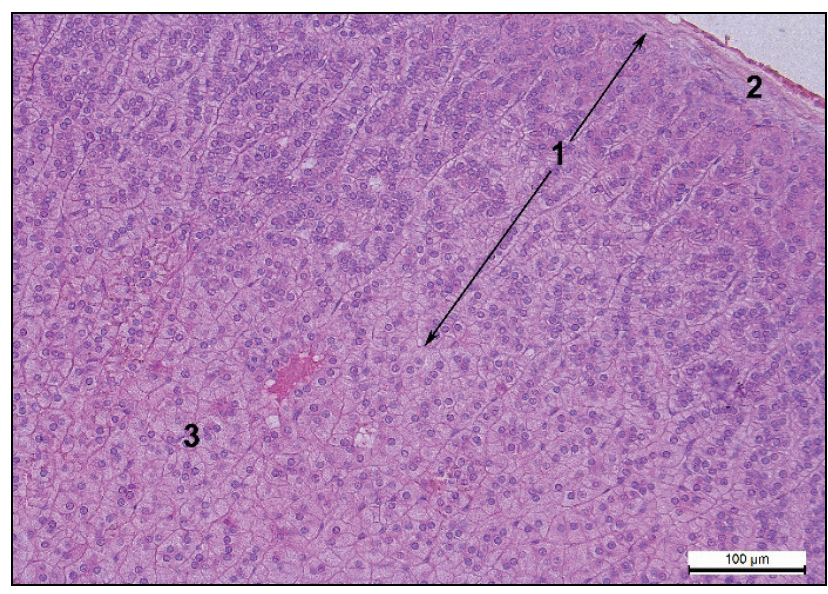

Fig. 4. Suprarenal gland of parasympathicotonic rabbit: 1 - zona glomerulosa, 2 - capsule, 3 -zona fasciculate; hematoxylin and eosin

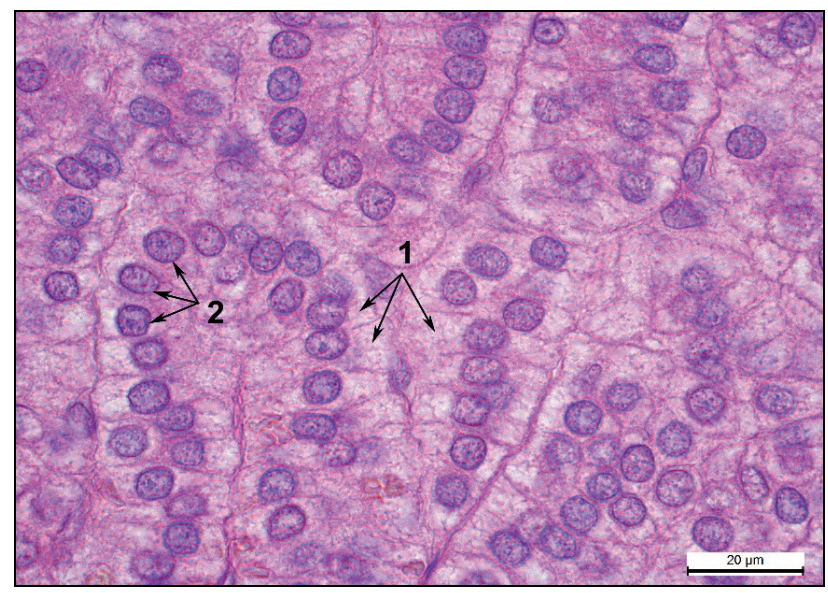

Fig. 5. Cells of the zona glomerulosa of parasympathicotonic rabbit: 1 - cell cytoplasm, 2 - nucleus; hematoxylin and eosin

Table 2

Number and sizes of separate cells $(\mathrm{x} \pm \mathrm{SE})$

\begin{tabular}{|c|c|c|c|}
\hline \multirow{2}{*}{ Indicator } & \multicolumn{3}{|c|}{ Group of rabbits } \\
\hline & sympathicotonic, $\mathrm{n}=19$ & normotonic, $\mathrm{n}=5$ & parasympathicotonic, $\mathrm{n}=3$ \\
\hline Number of cells in the zona glomerulosa per $1,000 \mu \mathrm{m}^{2}$ & $8.36 \pm 0.31$ & $8.26 \pm 0.88$ & $7.94 \pm 0.79$ \\
\hline Number of cells in the zona fasciculata per $1,000 \mu \mathrm{m}^{2}$ & $4.43 \pm 0.18$ & $5.14 \pm 0.45^{\text {aa }}$ & $4.82 \pm 0.64$ \\
\hline Number of cells of the zona reticularis per $1,000 \mu \mathrm{m}^{2}$ & $6.13 \pm 0.35$ & $4.91 \pm 0.77$ & $5.20 \pm 0.16$ \\
\hline Number of cells of the medulla per $1,000 \mu \mathrm{m}^{2}$ & $8.45 \pm 0.51$ & $8.53 \pm 0.68$ & $8.09 \pm 1.00$ \\
\hline Number of cells of the zona glomerulosa, $\mu \mathrm{m}^{2}$ & $104.5 \pm 4.2$ & $115.4 \pm 21.6$ & $117.7 \pm 8.3$ \\
\hline Area of cells of the zona fasciculata, $\mu \mathrm{m}^{2}$ & $210 \pm 15$ & $173 \pm 12$ & $156 \pm 25$ \\
\hline Area of cells of the zona reticularis, $\mu \mathrm{m}^{2}$ & $135.1 \pm 7.4$ & $158.5 \pm 3.3$ & $181.2 \pm 13.2$ \\
\hline Area of cells of the medulla, $\mu \mathrm{m}^{2}$ & $110.6 \pm 7.3$ & $97.5 \pm 13.7$ & $93.4 \pm 12.6$ \\
\hline Area of the nucleus of the zona glomerulosa, $\mu \mathrm{m}^{2}$ & $30.84 \pm 0.93$ & $30.76 \pm 1.79$ & $31.60 \pm 3.10$ \\
\hline Area of nucleus of the zona fasciculata, $\mu \mathrm{m}^{2}$ & $34.2 \pm 1.2$ & $32.2 \pm 1.4$ & $33.3 \pm 1.1$ \\
\hline Area of nucleus of cell of the zona reticularis, $\mu \mathrm{m}^{2}$ & $32.5 \pm 1.1$ & $38.8 \pm 6.4$ & $32.1 \pm 5.0$ \\
\hline Area of cell nucleus of the medulla, $\mu \mathrm{m}^{2}$ & $32.7 \pm 2.0$ & $30.8 \pm 3.0$ & $30.9 \pm 3.4$ \\
\hline Nuclear-cytoplasmic ratio of cells of the zona glomerulosa & $0.419 \pm 0.019$ & $0.363 \pm 0.047^{\text {aaa }}$ & $0.367 \pm 0.045^{\text {аaа }}$ \\
\hline Nuclear-cytoplasmic ratio of cells of the zona fasciculata & $0.195 \pm 0.016$ & $0.229 \pm 0.023^{\text {aа }}$ & $0.271 \pm 0.035^{\text {aaabb }}$ \\
\hline Nuclear-cytoplasmic ratio of cells of the zona reticularis & $0.317 \pm 0.018$ & $0.324 \pm 0.062$ & $0.215 \pm 0.061^{\text {aaabb }}$ \\
\hline Nuclear-cytoplasmic ratio of cells of the medulla & $0.420 \pm 0.021$ & $0.462 \pm 0.023^{\mathrm{a}}$ & $0.494 \pm 0.032^{\text {aab }}$ \\
\hline
\end{tabular}

Note: ${ }^{\text {a }}$ - statistically reliable difference compared with the group of sympathicotonic rabbits $\left({ }^{a}-\mathrm{P}<0.05 ;{ }^{\text {a }}-\mathrm{P}<0.01 ;{ }^{\text {aa }}-\mathrm{P}<0.001\right) ;{ }^{\text {b }}-$ statistically reliable difference compared with the group of normotonic rabbits $\left({ }^{b}-\mathrm{P}<0.05 ;\right.$; $\left.-\mathrm{P}<0.01\right)$. 


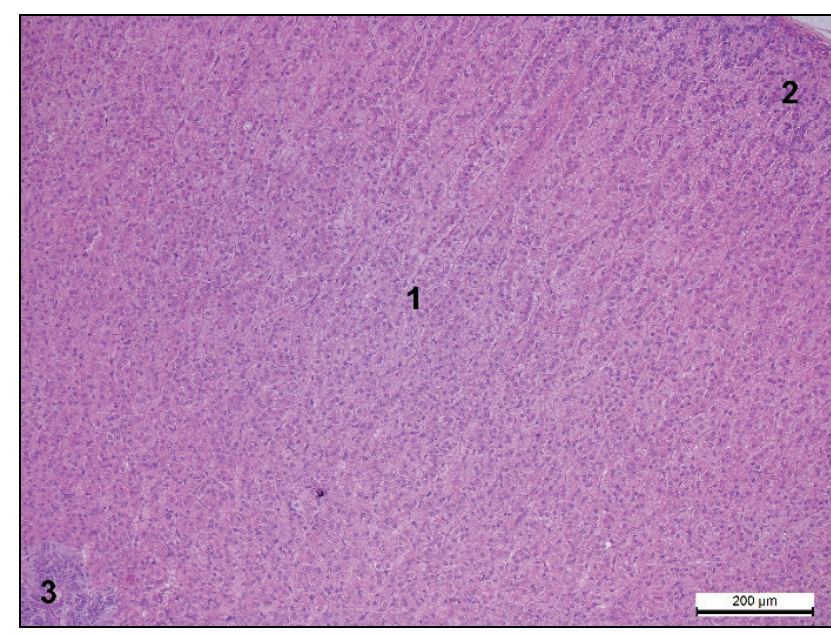

Fig. 6. The suprarenal gland of normotonic rabbit: $1-$ zona fasciculata, 2-zona glomerulosa, 3-medulla; hematoxylin and eosin

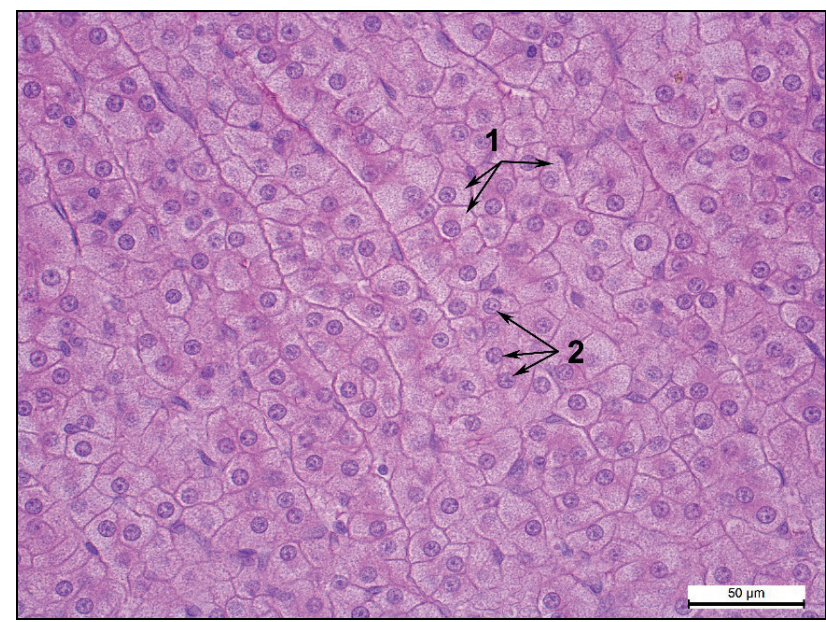

Fig. 7. Cells of the zona fasciculata of normotonic rabbit: 1 - cell's cytoplasm, 2 - cell's nucleus; hematoxylin and eosin

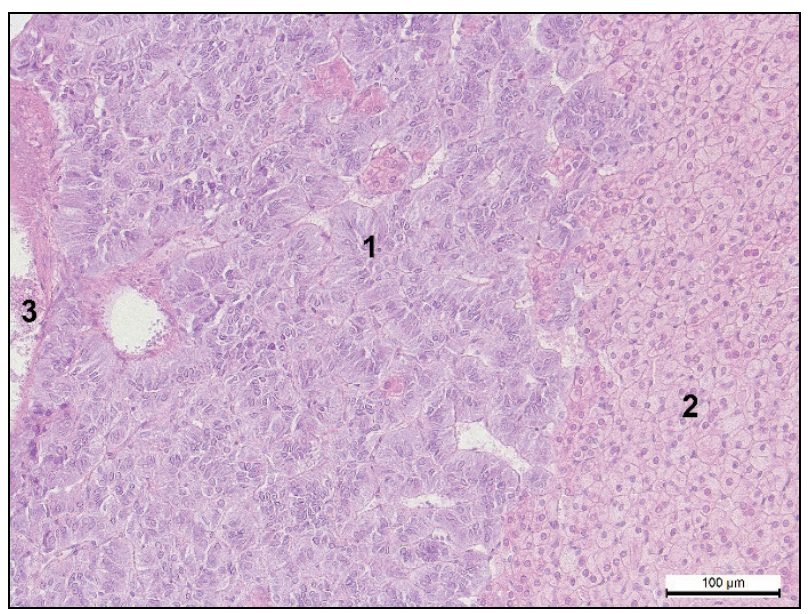

Fig. 8. The suprarenal gland of sympathicotonic rabbit: 1 - medulla, 2 -zona reticularis, 3 -zona fasciculata, 4 - central vein; hematoxylin and eosin

In four sympathicotonic animals, in one normotonic and one parasympathicotonic rabbit the medulla was fragmented (Fig. 11, 12). This is related to peculiarities of embryogenesis of this genus of mammals (Sokolov, 1969). Therefore to characterize its forms we measured not only the areas, but lengths and widths of this zone. The largest medulla by area was observed in sympathicotonic rabbits $-6.74 \pm 5.33 \mathrm{~mm}^{2}$ (Table 1). In animals of other groups, this parameter was significantly lower: by $6.40 \mathrm{~mm}^{2}$ in normotonic and by $5.98 \mathrm{~mm}^{2}$ in parasympathicotonic animals. Number of cells of the medulla in the area of $1,000 \mu \mathrm{m}^{2}$ in ST and NT rabbits differed by 0.08 units with higher number in the animals of the second group. In parasympathicotonic animals this parameter was 0.36 units less than the parameters of sympathicotonic animals (Fig. 13).

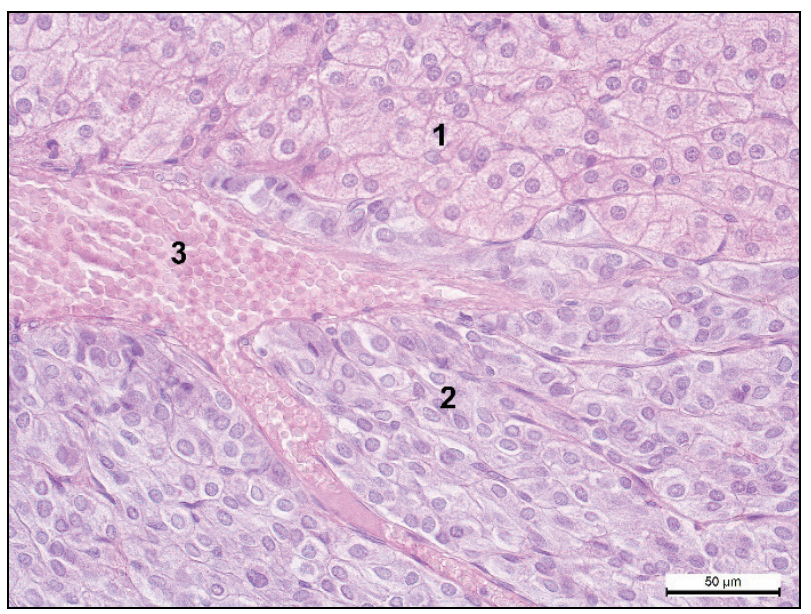

Fig. 9. Suprarenal gland of sympathicotonic rabbit: 1 -zona reticularis, 2 - medulla, 3-central vein; hematoxylin and eosin

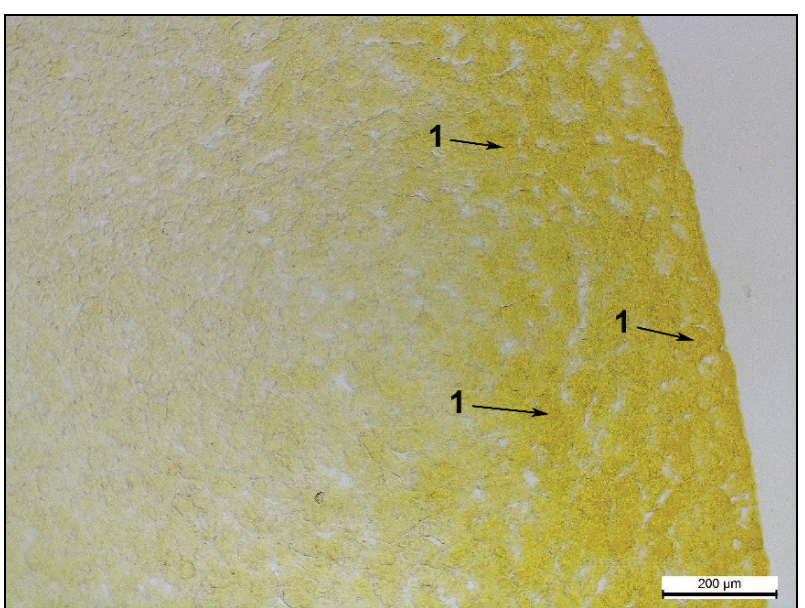

Fig. 10. Accumulation of corticosteroids in the cortex zone of normotonic rabbit (1): phenylhydrazine reaction

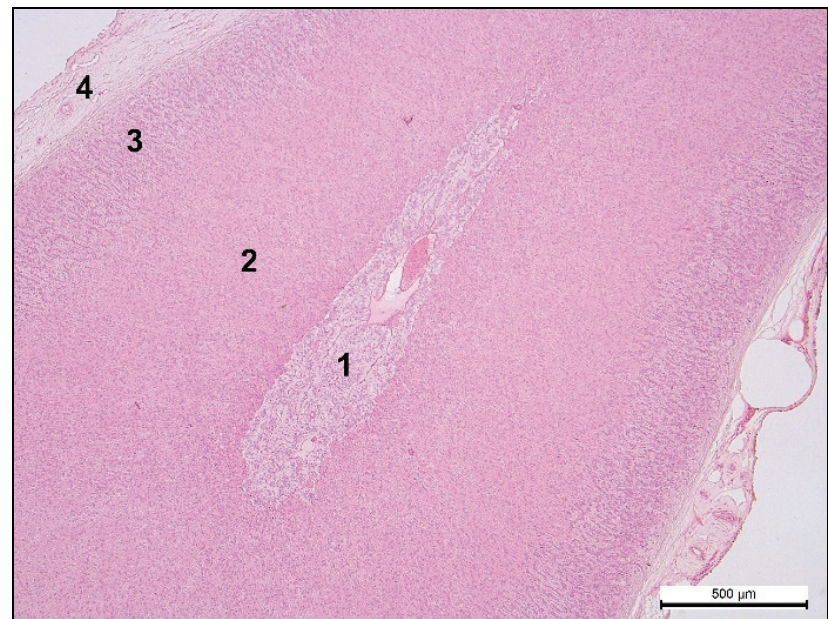

Fig. 11. Suprarenal gland of sympathicotonic rabbit:

1 - total (not fragmented) medulla, 2 - zona fasciculata,

3 -zona glomerulosa, 4-capsule; hematoxylin and eosin

Highest values of length of the medulla were observed in normotonic animals $(2,941 \pm 1,243 \mu \mathrm{m})$. Width of this zone was the greatest in sympathicotonic rabbits $(809 \pm 144 \mu \mathrm{m})$, which was by $502 \mu \mathrm{m}$ higher than in normotonic animals, and by $375 \mu \mathrm{m}$ than in parasympathicotonic ones. 


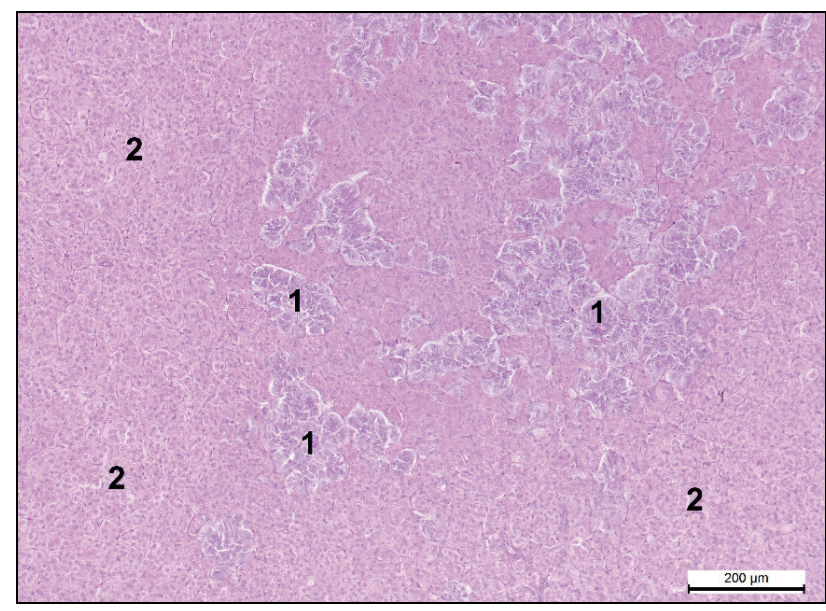

Fig. 12. Suprarenal gland of sympathicotonic rabbit: 1 - fragmented medulla, 2 - cortex zone; hematoxylin and eosin

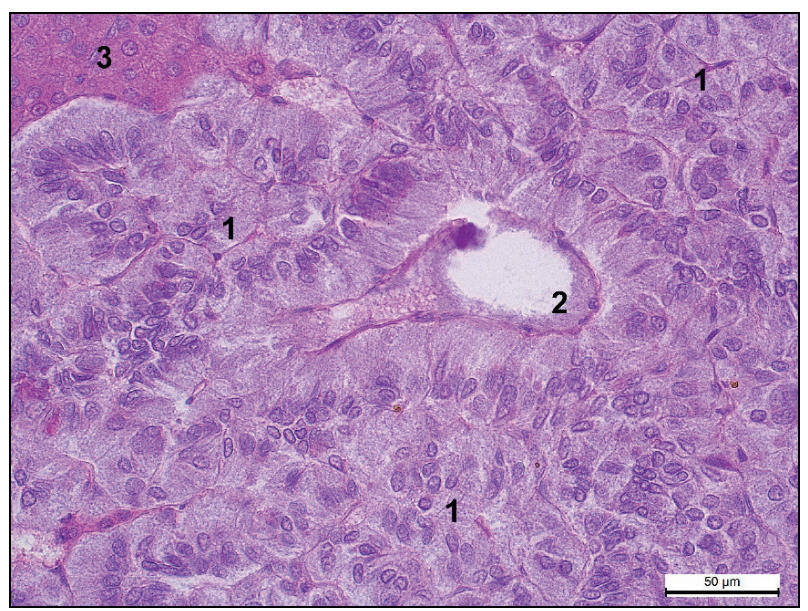

Fig. 13. Suprarenal gland of sympathicotonic rabbit: 1 - medulla,

2 - central vein, 3 -zona reticularis; hematoxylin and eosin

Because the sizes of the medulla significantly differed in all examined groups of animals, we determined the ratio between its length and width, which equaled 3:3 in sympathicotonic, 9.6 in normotonic and 6.7 - in parasympathicotonic rabbits. These parameters allow us to understand that in NT rabbits the shape of the medulla was most elongated compared with the other groups of animals.

Despite the fact that the medulla was biggest in ST rabbits, the area of location of catecholamines in it was the largest in NT rabbits. In sympathicotonic animals (Fig. 14) it was smaller by $440 \mu \mathrm{m}^{2}$.

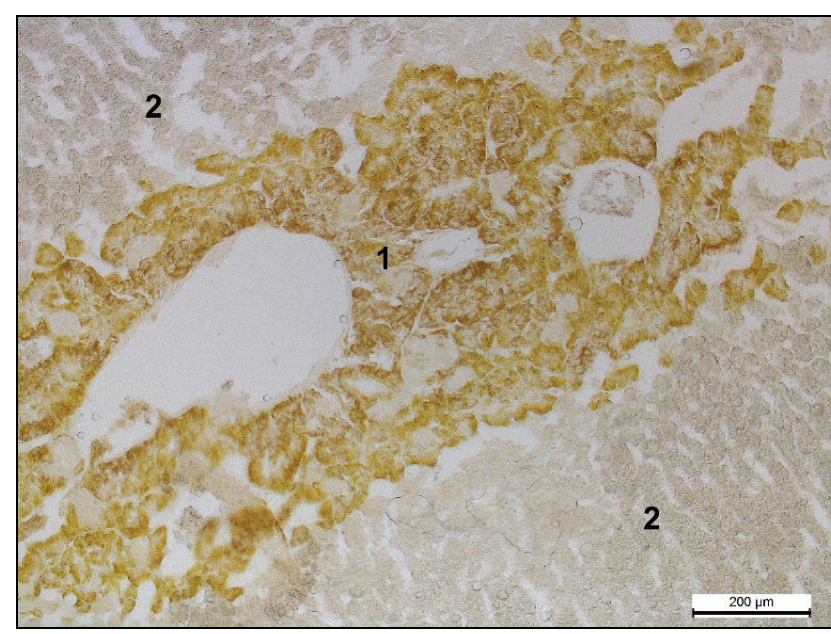

Fig. 14. The suprarenal gland of sympathicotonic rabbit: 1 - accumulation of hormones in cells of the medulla, 2 - cortex zone; chromaffin reaction according to the method by Hillarp and Hokfelt
The lowest parameters of the area of catecholamines corresponded to parasympathicotonic rabbits, in which they were less by $40 \mu \mathrm{m}^{2}$ compared with sympathicotonic animals. For more detailed characteristic of the cellular component of the suprarenal glands, we performed morphometry of cells and their nuclei, and also determined nuclear-cytoplasmic ratios in separate zones. In all cases we observed no significant difference between three groups of rabbits by the parameters of both area of cells and their nuclei in the examined zones.

Compared with the previous parameters, the nuclear-cytoplasmic ratio showed significant differences between the animal groups. In the zona fasciculata and medulla the highest value of this parameter belonged to parasympathicotonic rabbits, and the lowest were observed in sympathicotonic animals. The difference between the groups was $0.076(\mathrm{P}<$ $0.001)$ and 0.074 units $(\mathrm{P}<0.01)$ respectively. By obtaining average values of nuclear-cytoplasmic ratio in these zones, NT rabbits exceeded ST animals respectively by $0.034(\mathrm{P}<0.01)$ and 0.042 unit $(\mathrm{P}<0.05)$.

In the zona glomerulosa, ST rabbits had highest values of nuclearcytoplasmic ratio. In NT and PS animals this parameter was almost the same and was lower than in the previous group respectively by $0.056(\mathrm{P}<$ $0.001)$ and 0.052 units $(\mathrm{P}<0.001)$.

Value of nuclear-cytoplasmic ratio in the zona reticularis was highest in NT rabbits. In sympathicotonic animals it was observed to be lower only by 0.007 units. In parasympathicotonic rabbits this parameter was much lower, differing from ST animals by 0.102 units $(\mathrm{P}<0.001)$. A characteristic feature of only nuclear-cytoplasmic ratio is presence of reliable differences between normotonic and parasympathicotonic rabbits. In the zona fasciculata and medulla of PS rabbits it was higher compared with NT respectively by 0.042 units $(\mathrm{P}<0.01)$ and 0.032 units $(\mathrm{P}<0.05)$, and in the zona reticularis it was lower by 0.109 unnits $(\mathrm{P}<0.001)$.

During histological survey of glycogen, glycoproteins and glycosaminoglycans, we determined that PAS-positive substances (Fig. 15) were present only in the intracellular connective tissue and capsule of the suprarenal gland in all groups of rabbits. Acidic glycosaminoglycans in the tissue of the gland and capsule were completely absent.

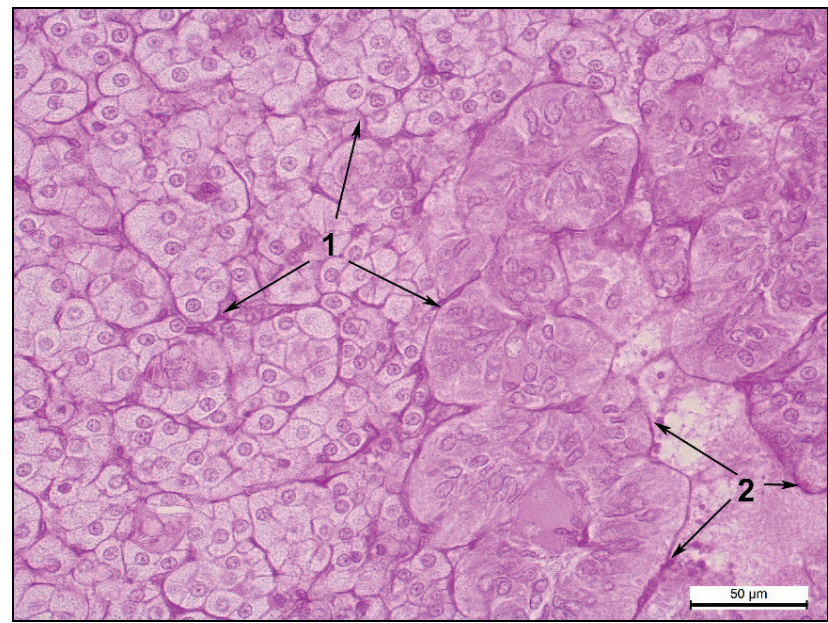

Fig. 15. PAS-positively stained connective tissue ( 1 ) and endothelium of the vessel (2) of the suprarenal gland of sympathicotonic rabbit; PAS-reaction according to Mc Manus

Typological peculiarities of the autonomic tone are also reflected in the parameters of the animals' body weight. In sympathicotonic and normotonic rabbits this parameter was almost the same - respectively $3.68 \pm 0.10$ and $3.67 \pm 0.24 \mathrm{~kg}$. That is difference between these groups was only $0.01 \mathrm{~kg}$. Parasympathicotonic rabbits had the highest body weight $(3.92 \pm 0.43 \mathrm{~kg})$, exceeding the weight of ST rabbits by $0.24 \mathrm{~kg}$.

\section{Discussion}

The conducted studies revealed that typological peculiarities of the autonomic tone manifests in morphological peculiarities of the suprarenal glands of rabbits. Intensity of autonomic impacts on different parameters was not the same. During the morphometry of the capsule of the gland, 
thickness of the capsule of sympathicotonic rebbits was found to be twice as large as in animals of other groups, which is related to large amount of fatty tissue between the fibers of the connective tissue. Furthermore, in the gland's capsule we found areas with cells of the cortex zone. This can indicate fast embryogenesis of the suprarenal glands in ST animals, due to which epithelial and nervous tissues of their suprarenal glands do not complete their fusion completely (Keegan \& Hammer, 2002; Rupik, 2002; Sheikhian et al., 2014). This was also confirmed by the data of Vidal et al. (2016), according to which the suprarenal glands contain subcapsular blastema, cells of which can further differentiate and during regenerative processes become round, accumulate lipid droplets and become cells of the zona glomerulosa. However, not all researchers (Katsnelson, 1968) agree with these data, because consider that during embyogenesis usual cells of the cortex zone intervened in the structure of the capsule, and according to the recent reports, not only they but also cells of adrenogonadal primordium (Bandiera et al., 2013; Dörner et al., 2016). The determined peculiarities allow us to consider the suprarenal gland's capsule not only as a protective structure, but also indicate its important role in the processes of adaptation of the gland's morphology to trophic-regulatory impacts from the autonomic tone.

The survey of the structure of the cortex zone of the gland revealed that its division into separate functional zones (glomerulosa, fasciculata and reticularis zones) is not clear and the borders between them are blurred. This is explained by the fact that during the embryonic period the cortex of the suprarenal glands is represented by an interrenal gland with non-differentiated cells (Barwick et al., 2005; El-Nahla et al., 2011; Xing et al., 2015). Formation of the zona glomerulosa and zona fasciculata (Sokolov, 1972; Kataoka, 1996; Lotfi et al., 2018) begins only in the second half of the embryonic development. A number of authors (Freedman et al., 2013; Pihlajoki et al., 2015) state that the cells of the zona glomerulosa can change and become cells of zona fasciculata. The zona reticularis is considered a derivative of the juxtamedullary zone (homologue of the fetal cortex of mammals and X-zone of mice) and differentiates during the postnatal period (Sedova, 1974; Huang \& Kang, 2019). However, Vidal et al. (2016) indicate that this zone forms in people, but is absent in rodents.

As for the non-uniformity of the arrangement of the medulla and zona reticularis, or complete absence of the latter which we observed in some rabbits, this was probably caused by embryonic of ingrowth of the chromaffin tissue (future cortex zone) into the interrenal gland, which takes place in two stages. During the unification of the progenitors of cortical and medullary substances, they can move, which is obviously the reason for their fragmentary nature (Sokolov, 1972). At the same time, the medulla underwent fragmentation only in one PS rabbit, and cells of the zona reticularis were found only in two rabbits, which was $67 \%$ of all the examined animals of that group. In NT animals, the zona reticularis was found in $40 \%$ of animals, and fragmented medulla in $20 \%$ of the cases. In the ST group, $74 \%$ of the animals had zona reticularis and only $37 \%$ were observed to have fragmentation of the medulla. During the study of the cellular composition of the suprarenal glands' medulla, we found only one type of cells - chromaffin cells (epinephrocytes, A-cells), which produce two types of hormones of this zone. This correlates with the data of other scientists (Kruglova, 1975). These cells form separate accumulations, i.e. are represented in the form of cluster structures (Hussein et al., 2015). By contrast to rabbits, in cattle and some marine mammals, in the medulla, two types of cells located in the layers are distinguished. Epinephrocytes are located on the periphery of the medulla, and the norepinephrocytes in the centre (Clark et al., 2005; Vuković et al., 2010; Barszcz et al., 2016). Also shifts of the medulla towards the periphery of the gland were observed in $42 \%$ of ST rabbits. Instead, in NT rabbits this peculiarity was observed only in $20 \%$ of the cases, and in PS animals the shifts of the medulla were not observed at all. The presented differences in topography of separate zones of the suprarenal glands can be functionally conditioned, though this requires further study.

During the survey of PAS-positive substances (glycoproteins, polysaccharides, mucopolysaccharides, glycolipids), we determined their presence in intracellular space of all the gland's zones. However, no PASpositive substances were found in cytoplasm of the cells. This indicates absence of intracellular reserves of glycoprotein in the suprarenal glands of adult rabbits. At the same time, Mezhnin (1970) found accumulation of glycogen in the interrenal cells of 7-day embryos of chickens. This can be conditioned by the species factor, or related to age change in the functional activity of these cells.

\section{Conclusions}

Typological peculiarities of the autonomic tone have a diverse effect on the structure of the suprarenal glands of rabbits. Normotonic animals had the least body weight and suprarenal glands with the thinnest capsule and average sizes of the glomerulosa and fasciculate zones. The zona fasciculata and medulla were the most saturated with cells. Nuclear-cytoplasmic ratio in the zona glomerulosa of NT rabbits was the lowest, while in zona reticularis it was the highest. Also NT rabbits were characterized by the largest area of corticosteroids. Parasympathicotonic rabbits had the greatest body weight and thickness of the zona glomerulosa, but the thinnest zona fasciculata. The zona glomerulosa had the lowest amount of cells and the smallest area of corticosteroids. The zona fasciculata and zona reticularis were characterized by highest values of nuclear-cytoplasmic ratio. Sympathicotonic animals had the highest values of the capsule's thickness, width of the medulla, number of cells per $1,000 \mu \mathrm{m}^{2}$ of the glomerulosa and reticularis zones, area of cells of zona fasciculata and medulla, area of the nucleus of cell of zona fasciculata and medulla, and also nuclear-cytoplasmic ratio of cells of the zona glomerulosa.

\section{References}

Baevskij, R. M., Kirilov, O. I., \& Kleckin, S. Z. (1984). Matematicheskij analiz serdechnogo ritma pri stresse [Mathematical analysis of cardiac rhythm in stress]. Nauka, Moscow (in Russian).

Baine, K., Newkirk, K., Fecteau, K., \& Souza, M. (2014). Elevated testosterone and progestin concentrations in a spayed female rabbit with an adrenal cortical adenoma. Case Reports in Veterinary Medicine, 239410.

Bandiera, R., Vidal, V. P., Motamedi, F. J., Clarkson, M., Sahut-Barnola, I., von Gise, A., Pu, W. T., Hohenstein, P., Martinez, A., \& Schedl, A. (2013). WT1 maintains adrenal-gonadal primordium identity and marks a population of AGP-like progenitors within the adrenal gland. Developmental Cell, 27, 5-18.

Barszcz, K., Przespolewska, H., Olbrych, K., Czopowicz, M., Klećkowska-Nawrot, J., Goździewska-Harłajczuk, K., \& Kupczyńska, M. (2016). The morphology of the adrenal gland in the European bison (Bison bonasus). BMC Veterinary Research, 12(1), 161

Barwick, T. D., Malhotra, A., Webb, J. A., Savage, M. O., \& Reznek, R. H. (2005). Embryology of the adrenal glands and its relevance to diagnostic imaging. Clinical Radiology, 60(9), 953-959.

Capaldo, A., Gay, F., De Falco, M., Virgilio, F., Laforgia, V., \& Varano, L. (2006). The adrenal gland of newt Triturus carnifex (Amphibia, Urodela) following in vivo betamethasone administration. Anatomy and Embryology, 211(6), 577-584

Chandra, S. V., \& Imam, Z. (1975). Effect of manganese on the morphology of the rabbit adrenal cortex. Arhiv za Higijenu Rada i Toksikologiju, 26(3), 201-207.

Chimenti, C., \& Accordi, F. (2013). Differentiation of steroidogenic cells in the developing adrenal gland of Testudo hermanni Gmelin, 1789 (chelonian reptiles). Anatomia, Histologia, Embryologia, 42(4), 275-284.

Clark, L. S., Pfeiffer, D. C., \& Cowan, D. F. (2005). Morphology and histology of the atlantic bottlenose dolphin (Tursiops truncatus) adrenal gland with emphasis on the medulla. Anatomia, Histologia, Embryologia, 34(2), 132-140.

Crivellato, E., De Falco, M., Capaldo, A., Laforgia, V., Ribatti, D., \& Luca, A. (2009). Chromaffin cells in the amphibian urodele triturus carnifex show ultrastructural features indicative of a vesicle-mediated mode of cell degranulation. The Anatomical Record Advances in Integrative Anatomy and Evolutionary Biology, 292(1), 73-78.

Dömer, J., Martinez Rodriguez, V., Ziegler, R., Röhrig, T., Cochran, R. S., Göt, R. M., Levin, M. D., Pihlajoki, M., Heikinheimo, M., \& Wilson, D. B. (2016). GLI1+ progenitor cells in the adrenal capsule of the adult mouse give rise to heterotopic gonadal-like tissue. Molecular and Cellular Endocrinology, 441, 164-175.

Dumbell, R., Matveeva, O., \& Oster, H. (2016). Circadian clocks, stress, and immunity. Frontiers in Endocrinology, 7, 37.

El-Nahla, S. M., Imam, H. M., Moussa, E. A., Elsayed, A. K., \& Abbott, L. C. (2011). Prenatal development of the adrenal gland in the one-humped camel (Camelus dromedarius). Anatomia, Histologia, Embryologia, 40(3), 169-186.

Fiadotau, D. N. (2015). The age histology adrenal medulla of the cattle. Theoretical and Applied Science, 22, 8-10.

Finco, I., \& Hammer, G. D. (2018). Isolation, fixation, and immunofluorescence imaging of mouse adrenal glands. Journal of Visualized Experiments, 140, 58530. 
Freedman, B. D., Kempna, P. B., Carlone, D. L., Shah, M. S., Guagliardo, N. A., Barrett, P. Q., Gomez-Sanchez, C. E., Majzoub, J. A., \& Breault, D. T. (2013). Adrenocortical zonation results from lineage conversion of differentiated zona glomerulosa cells. Developmental Cell, 26, 666-673.

Gallo-Payet, N., Martinez, A., \& Lacroix, A. (2017). Editorial: ACTH action in the adrenal cortex: From molecular biology to pathophysiology. Frontiers in Endocrinology, 8, 101.

Huang, C.-C., \& Kang, Y. (2019). The transient cortical zone in the adrenal gland: The mystery of the adrenal X-zone. Journal of Endocrinology, 241(1), 51-63.

Huber, K. (2006). The sympathoadrenal cell lineage: Specification, diversification, and new perspectives. Developmental Biology, 298, 335-343.

Huber, K., Combs, S., Ernsberger, U., Kalcheim, C., \& Unsicker, K. (2002). Generation of neuroendocrine chromaffin cells from sympathoadrenal progenitors: Beyond the glucocorticoid hypothesis. Annals of the New York Academy of Sciences, 971, 554-559.

Huber, K., Kalcheim, C., \& Unsicker, K. (2009). The development of the chromaffin cell lineage from the neural crest. Autonomic Neuroscience, 151(1), $10-16$.

Humayun, K. A. K. M., Aoyama, M., \& Sugita, S. (2012). Morphological and histological studies on the adrenal gland of the chicken (Gallus domesticus). The Journal of Poultry Science, 49(1), 39-45.

Hussein, A. A., Abass, T. A., Hussein, B. F., \& Yassin, M. M. (2015). Histomorphological developmental study of the adrenal gland of the local rabbit at one and fifteen days age. Al-Qadisiyah Journal of Veterinary Medicine Sciences, 14(2), 47-54.

Jelinek, F., \& Konecny, R. (2011). Adrenal glands of slaughtered bulls, heifers and cows: A histological study. Anatomia, Histologia, Embryologia, 40(1), 28-34.

Kataoka, Y., Ikehara, Y., \& Hattori, T. (1996). Cell proliferation and renewal of mouse adrenal cortex. Journal of Anatomy, 188(2), 375-381.

Katsnelson, Z. S. (1968). O tak nazyvaemoj kapsuljarnoj (subkapsuljarnoj) blasteme $\mathrm{v}$ nadpochechnike [On the so-called capsular (subcapsular) adrenal blastema]. Arhiv Anatomii, Gistologii i Embriologii, 54, 3-12 (in Russian).

Keegan, C. E., \& Hammer, G. D. (2002). Recent insights into organogenesis of the adrenal cortex. Trends in Endocrinology and Metabolism, 13(5), 200-208.

Kigata, T., \& Shibata, H. (2018). Arterial supply to the rabbit adrenal gland. Anatomical Science International, 93(4), 437-448.

Kononskiy, A. I. (1976). Gistohimiya [Histochemistry]. Vyshha Shkola, Kyiv (in Russian).

Kruglova, V. A. (1975). Gistologicheskoe issledovanie nadpochechnika u treh vidov pustynnyh zhivotnyh [Histological examination of the adrenal gland in three species of desert animals]. Arhiv Anatomii, Gistologii i Embriologii, 68(2), 4449 (in Russian).

Lofts, B., Phillips, J. G., \& Tam, W. H. (1971). Seasonal changes in the histology of the adrenal gland of the cobra, Naja naja. General and Comparative Endocrinology, 16(1), 121-131.

Lotfi, C. F. P., Kremer, J. L., Passaia, B. S., \& Cavalcante, I. P. (2018). The human adrenal cortex: Growth control and disorders. Clinics (Sao Paulo), 73(1), e473s.

McCreedy, C. D., \& Harmon, P. W. (1992). Sodium provision and wild cottontail rabbits: Morphological change in adrenal glands. The Journal of Wildlife Management, 56(4), 669-676.

Mezhnin, F. I. (1970). Gistohimicheskoe issledovanie gistogeneza nadpochechnika u domashnej kuricy [Histochemical study of adrenal gland histogenesis in domestic chicken]. Arhiv Anatomii, Gistologii i Embriologii, 59, 59-63 (in Russian).

Milano, E., \& Accordi, F. (1986). Evolutionary trends in adrenal gland of anurans and urodeles. Journal of Morphology, 189(3), 249-259.

Moawad, U. K., \& Randa, M. H. (2017). Histocytological and histochemical features of the adrenal gland of adult egyptian native breeds of chicken (Gallus domesticus). Journal of Basic and Applied Sciences, 6(2), 199-208.

Nicolaides, N. C., Charmandari, E., Kino, T., \& Chrousos, G. P. (2017). Stressrelated and circadian secretion and target tissue actions of glucocorticoids: Impact on health. Frontiers in Endocrinology, 8, 70.

Olukole, S., Adeagbo, M., \& Oke, B. (2016). Histology and histochemistry of the adrenal gland african giant rat (Cricetomys gambiamus, Waterhouse). International Journal of Morphology, 34(4), 1455-1460.

Orezzoli, A. A., Gonzalez, N. V., Villar, M. J., Hökfelt, T., \& Tramezzani, J. H. (1994). Histochemical study of chromaffin cells and nerve fibers in the adrenal gland of the flat snake (Waglerophis merremii). General and Comparative Endocrinology, 93(3), 411-423.

Parker, T. L., Kesse, W. K., Mohamed, A. A., \& Afework, M. (1993). The innervation of the mammalian adrenal gland. Journal of Anatomy, 183, 265-276.

Paul, B., Sarkar, S., Islam, M. N., \& Das, R. (2016). Morphological and histological investigations on the adrenal glands in black bengal goat (Capra hircus). Journal of the Sylhet Agricultural University, 3(2), 181-187.
Pihlajoki, M., Dörner, J., Cochran, R. S., Heikinheimo, M., \& Wilson, D. B. (2015). Adrenocortical zonation, renewal, and remodeling. Frontiers in Endocrinology, 6, 27.

Pirs, E. (1962). Gistohimija teoreticheskaja i prikladnaja [Theoretical and applied histochemistry]. Izdatel'stvo Inostrannoj Literatury, Moscow (in Russian).

Raharison, F., Bourges, A. N., Sautet, J., Deviers, A., \& Mogicato, G. (2017). Anatomy, histology and ultrasonography of the normal adrenal gland in brown lemur: Eulemur fulvus. Journal of Medical Primatology, 46(2), 25-30.

Ramey, E. R., \& Goldstein, M. S. (1957). The adrenal cortex and the sympathetic nervous system. Physiological Reviews, 37(2), 155-195.

Rupik, W. (2002). Early development of the adrenal glands in the grass snake Natrix natrix L. (Lepidosauria, Serpentes). Springer-Verlag, Berlin.

Santos, A. C., Viana, D. C., Bertassoli, B. M., Vasconcelos, B. G., Oliveira, D. M., Rici, R. E. G, Oliveira, M. F., Miglino, M. A., \& Assis-Neto, A. C. (2016). Adrenal glands of Spix's yellow-toothed cavy (Galea spixii, Wagler, 1831): Morphological and morphometric aspects. Brazilian Journal of Biology, 76(3), 645-655.

Sedova, E. V. (1974). Sopostavlenie fetal'noj kory i X-zony v nadpochechnike nekotoryh mlekopitajushhih [Comparison of the fetal cortex and X-zone in the adrenal gland of some mammals]. Arhiv Anatomii, Gistologii i Embriologii, 66(5), 77-82 (in Russian).

Sheikhian, A., Saadatfar, Z., \& Mohammadpour, A. (2014). A histological study of adrenal gland in guinea pig and hamster. Comparative Clinical Pathology, 24(5), 1069-1074.

Sokolov, V. I. (1969). Osobennosti soedinenija zachatkov interrenalovoj i suprarenalovoj zhelez i rannij gistogenez nadpochechnika u krolika [Features of the connection of the primordia of the interrenal and suprarenal glands and early adrenal histogenesis in a rabbit]. Arhiv Anatomii, Gistologii i Embriologii, 57(9), 13-19 (in Russian).

Sokolov, V. I. (1972). Gistogenez nadpochechnika zolotistogo homjaka v svjazi s problemoj h-zony [Golden hamster adrenal gland histogenesis due to h-zone problem]. Arhiv Anatomii, Gistologii i Embriologii, 63(7), 65-75 (in Russian).

Sonjoy, S., Nazrul, I., Gitaindro, N. A., Bashudeb, P., \& Nayan, B. (2014). Morphological and histological studies on the adrenal gland in male and female chicken (Gallus domesticus). International Journal of Biological and Pharmaceutical Research, 5(9), 715-718.

Sunwoo, S. H., Lee, J. S., Bae, S. J., Shin, Y. J., Kim, C. S., Joo, S. Y., Choi, H. S., Suh, M., Kim, S. W., Choi, Y. J., \& Kim, T. (2019). Chronic and acute stress monitoring by electrophysiological signals from adrenal gland. PNAS, 116(4), 1146-1151

Tachibana, T., Kusakabe, K. T., Osaki, S., Kuraishi, T., Hattori, S., Yoshizawa, M., Kai, C., \& Kiso, Y. (2015). Histocytological specificities of adrenal cortex in the New World Monkeys, Aotus lemurinus and Saimiri boliviensis. Journal of Veterinary Medical Science, 78(1), 161-165.

Unsicker, K., Huber, K., Schober, A., \& Kalcheim, C. (2013). Resolved and open issues in chromaffin cell development. Mechanisms of Development, 130, 324-329.

Vidal, V., Sacco, S., Rocha, A. S., da Silva, F., Panzolini, C., Dumontet, T., Doan, T. M., Shan, J., Rak-Raszewska, A., Bird, T., Vainio, S., Martinez, A., \& Schedl, A. (2016). The adrenal capsule is a signaling center controlling cell renewal and zonation through Rspo3. Genes and Development, 30(12), 1389-1394.

Vinson, G. P. (2016). Functional zonation of the adult mammalian adrenal cortex. Frontiers in Neuroscience, 10, 238.

Vinson, G. P., Pudney, J. A., \& Whitehouse, B. J. (1985). The mammalian adrenal circulation and the relationship between adrenal blood flow and steroidogenesis. Journal of Endocrinology, 105(2), 285-294

Vuković, S., Lucić, H., Zivković, A., Duras Gomercić, M., Gomercić, T., \& Galov, A. (2010). Histological structure of the adrenal gland of the bottlenose dolphin (Tursiops truncatus) and the striped dolphin (Stenella coeruleoalba) from the Adriatic Sea. Anatomia, Histologia, Embryologia, 39(1), 59-66.

Xing, Y., Lerario, A. M., Rainey, W., \& Hammer, G. D. (2015). Development of adrenal cortex zonation. Endocrinology and Metabolism Clinics of North America, 44(2), 243-274

Ye, L. X., Wang, J. X., Li, P., \& Zhang, X. T. (2018). Distribution and morphology of ghrelin immunostained cells in the adrenal gland of the African ostrich. Biotechnic and Histochemistry, 93(1), 1-7.

Zakrevska, M., \& Tybinka, A. (2019). Gistologichna harakterystyka dodatkovyh nadnyrkovyh zaloz kroliv z riznymy typamy avtonomnogo tonusu [Histological characteristics of accessory adrenal glands of rabbits with different types of autonomous tonus]. Scientific Messenger of LNU of Veterinary Medicine and Biotechnologies, Series Veterinary Sciences, 21, 125-130 (in Ukrainian).

Zhedenov, V. N. (1987). Anatomija krolika [Rabbit anatomy]. Sovetskaja Nauka, Moscow (in Russian). 